\title{
A shift from lithostratigraphic to allostratigraphic classification of Quaternary glacial deposits
}

\author{
M.E. Räsänen, Department of Geology, University of Turku, \\ 20014 Turku, Finland, matti.rasanen@utu.fi; J.M. Auri, \\ Geological Survey of Finland, Vaasantie 6, 67100 Kokkola, \\ Finland; J.V. Huitti, A.K. Klap, and J.J. Virtasalo, Department \\ of Geology, University of Turku, 20014 Turku, Finland
}

\begin{abstract}
The bedrock of the northern halves of North America and Europe is covered by Quaternary glacial deposits, forming a surficial overburden that is relatively thin, nonlithified, lithologically variable on a small scale (in terms of grain-size, mineralogy, texture, fabric, structure, and color), and often has a well-preserved depositional topography. These geologically unique characteristics and the fact that the glacial overburden was long considered to be of only restricted economic value have caused it to be treated differently in geological research from the older, regularly lithified strata. Due to the striking geomorphology of these glacial deposits, their investigation has also been incorporated into physical geography research. Thus, the segregation of the Quaternary research community into different schools of geology and geography has created multiple classification approaches and has caused the formal stratigraphic classifications successfully applied in pre-Quaternary geology to be applied less regularly to Quaternary glacial strata. This has led to inefficient use of Quaternary geological data for scientific and socio-economic purposes.

The few currently existing national Quaternary stratigraphic frameworks are based on lithostratigraphy. These are poorly suited for describing deposits in glaciated shield areas in particular; we propose a classification for such areas based on the combined use of allostratigraphic and lithostratigraphic data, with alloformations as the fundamental units and lithostratigraphic units filling out the framework where appropriate. This classification would provide a hierarchical framework for glaciogenic deposits that could potentially support stratigraphic information systems, databases, and digital spatial models more effectively than the traditional lithostratigraphic frameworks.
\end{abstract}

\section{INTRODUCTION}

A considerable proportion of the developed societies in Europe and North America are located in temperate terrain that was repeatedly glaciated during the cold climatic cycles of the Quaternary Period (the past 2.6 m.y.). It is important for future development in these areas that geologists be able to provide society with more accurate information on the past behavior and distribution of the continental ice sheets and the present structure and nature of the resulting glacial deposits. When this spatial and descriptive stratigraphic information can be correlated with the unusually good decadal and even annual high- resolution oxygen isotope and other geochemical or varve chronologies available from Quaternary marine, lake, and glacial ice records (Gibbard et al., 2007; Brauer and Negendank, 2004; see Fig. 1), it should be possible to construct local highresolution chronostratigraphic and diachronic time stratigraphies (cf. Johnson et al., 1997; Karrow et al., 2000). This time stratigraphic information would in turn enable more reliable long-term local climate, glacial, and sea-level scenarios to be provided to assist in resolving the heated worldwide discussion on the anthropogenic and/or natural reasons behind the present global warming (IPCC, 2007) and to inform decisions regarding nuclear waste disposal strategies in glaciated terrains (Heathcote and Michie, 2004).

Many societies are investing heavily in infrastructure to be built on and in deposits belonging to glacial landscapes while at the same time they are dependent on the characteristics of the glaciogenic terrains, including their groundwater and extractive resources. The existence of problematic geotechnical questions, landslide risks, contaminated land, and brown field problems and the relevance of Quaternary deposits to agriculture and forestry are examples of other issues societies face with regard to glaciogenic terrains. Intensified land use in metropolitan areas has caused a particular need to improve control over all types of geotechnical and geochemical data referring to Quaternary deposits, and data management should in any case be improved in order to enhance the sustainable use of land in all types of regional planning (European Union, 2007). This land-use planning would greatly benefit from the existence of practical stratigraphic classification systems and formal stratigraphic frameworks interconnected with flexible national and international geologic databases. The existing traditional soil and lithologic-lithogenetic surface maps clearly no longer provide the level of information needed in detailed planning, construction, and environmental projects (McMillan, 2005). Instead, there is an increased need for three-dimensional (3-D) stratigraphical information.

It has generally been thought that the lithostratigraphic classification used most commonly in pre-Quaternary geology, which is based on lithostratigraphic units, which are "bodies of rocks that are defined and recognized on the basis of their observable and distinctive lithologic properties or combination of lithologic properties and their stratigraphic relations" (Salvador, 1994), cannot be used as successfully in the case of glaciogenic Quaternary deposits, at least not in glaciated shield areas. This is due to the complexity and small-scale variation of the lithologic units in these deposits (cf. Flint, 1957; Eyles et al., 1984; Miall, 1997).

Some developed countries have recently made countrywide efforts to develop lithostratigraphic procedures for classifying their Quaternary glacial and non-glacial overburden, as exemplified by the work of the Deltares (Weerts et al., 2005; Weerts 


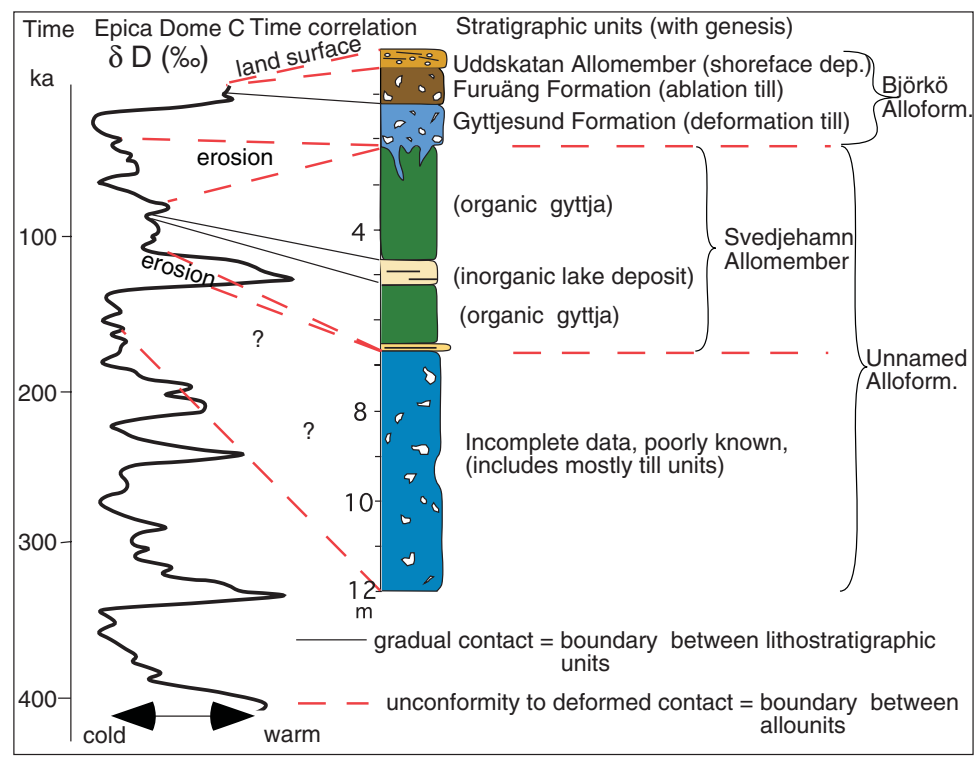

Figure 1. A principal example of correlating stratigraphic units with ice-core geochemical stratigraphy with high-resolution chronology. Stratigraphic units (modified from Auri, 2006) at a location in the central area of the Scandinavian glaciation are tentatively timecorrelated with the ice-core chronology from Antarctica (EPICA community members, 2004). The $\delta \mathrm{D}(\%$ o) (D is deuterium) values of the EPICA Dome $\mathrm{C}$ data are interpreted as reflecting global temperature changes during the past 400 k.y. In this case, the stratigraphic units are interpreted to have deposited in the course of the cool stadials and warmer interstadials. The correlation is rough, and the diachronism of climatic and glacial processes has to be taken into account in these types of correlations. Organic gyttja-organic lake deposit.

and Westerhoff, 2007), the Minnesota State Geological Survey (MGS; Johnson, 2005), and the British Geological Survey (BGS; McMillan, 2005).

But how successfully do the Deltares, MGS, and BGS classifications overcome the problem of high-frequency lithological variation in glaciated terrains? The Deltares and MGS approaches follow a tradition in which lithostratigraphic classification is applied quite freely, so that the lithostratigraphic formations defined in the Deltares classification, for example, represent depositional systems and basin fills, with a great variety of lithologies (Weerts et al., 2005). The Deltares and MGS usages follow the definition of the international guides (Salvador, 1994; North American Commission for Stratigraphic Nomenclature [NACSN], 2005) quite loosely, so that the higher hierarchy subgroups, groups, and supergroups in the Deltares classification are interpretative or geographically determined units and are not always related to the principles of lithostratigraphic classification.

The BGS classification defines a formation in a somewhat stricter manner, and the resulting lithostratigraphic formations are smaller in scale and generally show greater lithologic homogeneity (understood in a more petrographic sense). At the higher subgroup and group levels, the BGS scheme intends to show the lithologic (= petrographic) homogeneity in formations derived from the same provenance areas.

Because unconformities and small-scale lithologic variations are so abundant and are of primary importance in Quaternary glaciogenic deposits (Flint, 1957; Eyles et al., 1983; Miall, 1997), especially in shield areas, a practical approach involving the combined use of allostratigraphy and ithostratigraphy (CUAL) is proposed here. The new features in this descriptive CUAL approach are (1) unconformity-bounded allostratigraphic units are given preference as basic units, which means that all depositional units within an area will belong to a certain alloformation; and (2) these allounits are then subdivided into lithostratigraphic or lower-order allounits as appropriate (Figs. 1 and 4-6). As in sequence stratigraphy (Vail et al., 1977; Gutteridge, 2008) or glacial sequence stratigraphy (Powell and
Cooper, 2002), the unconformity-bounded units are the primary genetic units to be identified, with predictive textural and structural architecture.

\section{QUATERNARY STRATIGRAPHY IN GLACIATED TERRAINS}

The major reasons Quaternary researchers have had problems applying lithostratigraphy to glaciated terrain deposits can be summarized as follows (cf. Flint, 1957; Eyles et al., 1984; Miall, 1997):

1. Quaternary glaciogenic deposits often miss the fundamental gross lithologic changes (in grain-size, mineralogy, texture, fabric, structure, and color), which are more common in older rock series and aid in their lithostratigraphic classification. Quaternary deposits represent shorter periods of time and less fundamental paleoenvironmental changes in the provenance areas or in the post-depositional weathering or diagenesis of the sediments than in older strata.

2. Minor-scale gross lithological variation and local provenance is common when the bedrock type varies considerably, and transport distances are generally short in glacial systems (Figs. 2 and 3).

3. Lithologically similar units can be relatively small in scale, their thicknesses can vary frequently, and the units often occur as isolated deposits. This is because deposition occurred within laterally migrating, advancing, or retreating zones of glacial deposition, where rapid base-level changes occurred due to glacio-isostasy and/or eustasy or because the sediment input channels changed position laterally along the glacial margin (cf. Flint, 1957; Brookfield and Martini, 1999). These characteristics are especially prominent in the Canadian and Fennoscandian shield areas, where the pre-Quaternary bedrock topography tightly controlled the accommodation space during deposition.

4. Finally, due to the dynamic erosional and depositional processes combined with the repeated pattern of glacial cycles, unconformities and diastems are very common in Quaternary deposits, and lithostratigraphy does not use these features as primary classification criteria (Walker and James, 1992; Miall, 1997; NACSN, 2005). 


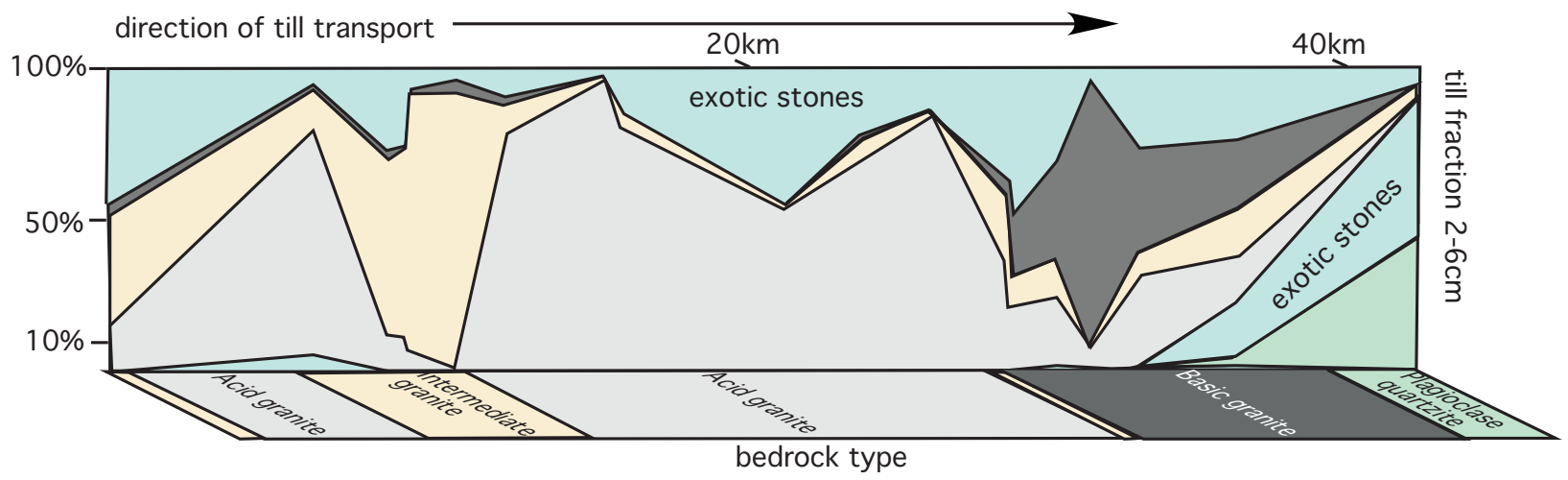

Figure 2. Petrographic variations in the coarse fraction of the Late Weichselian till bed in relation to the underlying Precambrian bedrock type within a $40 \mathrm{~km}$ transect parallel to the Late Weichselian ice movement in central Sweden. Only one till bed has been reported within the area. The exotic stone types refer to types that have not been encountered in the bedrock of the transect. Gray-acid granite; tan —intermediate granite; black-basic granite; teal—plagioclase quartzite; blue-exotic stones. Modified from Linden (1975).

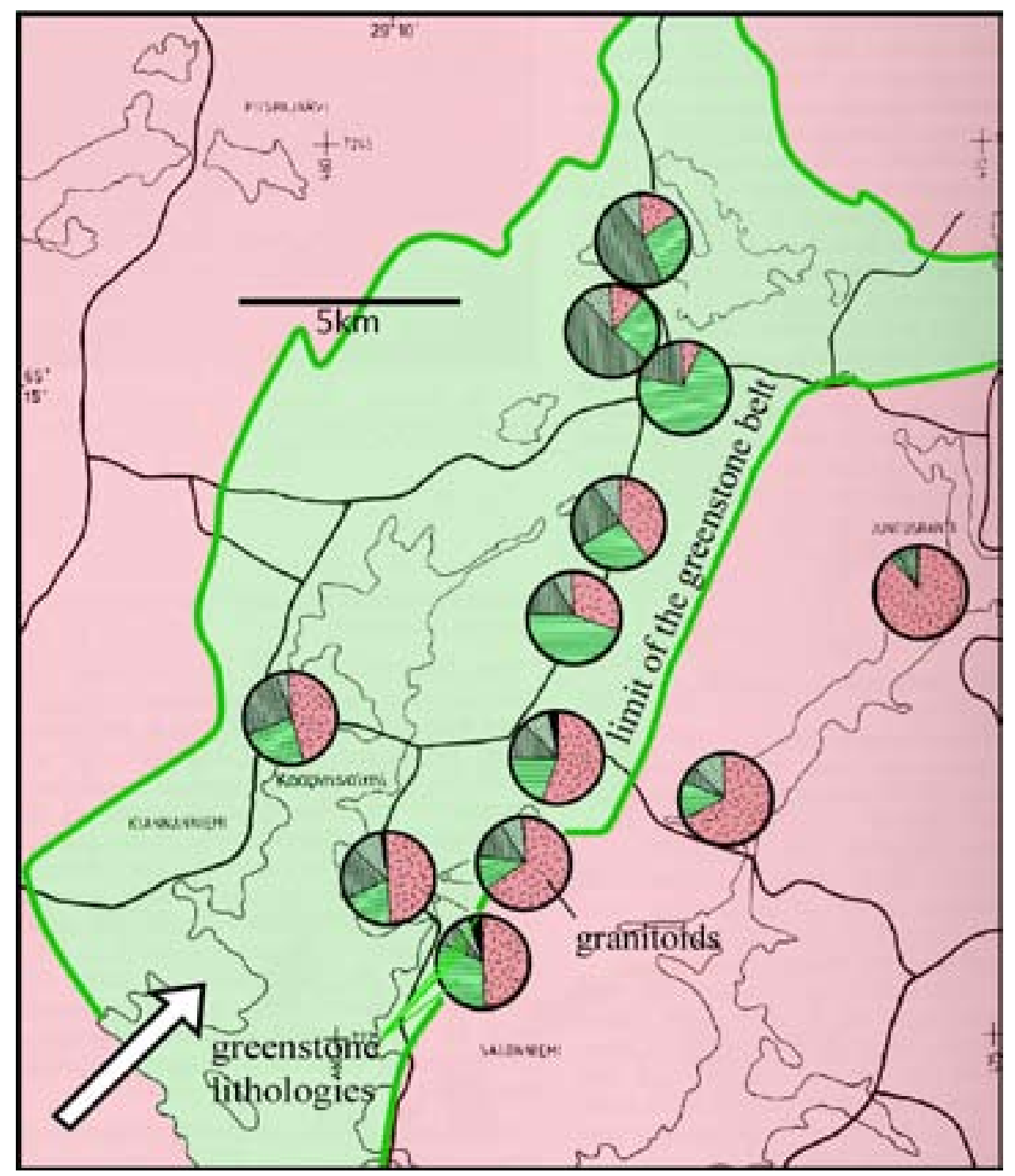

Figure 3. Petrographic variation of the coarse fraction of an unconformity-bounded till bed (pie charts) showing the influence of an Archean greenstone belt surrounded by granitoids on the composition of the coarse fraction of the till bed. Arrow shows direction of ice flow during deposition. The studied till bed is the lowermost of the tree unconformity-bounded till beds in eastern Finland. Modified from Saarnisto and Peltoniemi (1984). 
This leads to a situation in which reasonably homogeneous lithostratigraphic units are often so small in scale that they are not easily mappable (cf. Eyles et al., 1983, 1984; Miall, 1997). This contrasts markedly with the lithostratigraphic classification of most pre-Quaternary rocks, where the units are more broadly representative in time and space.

\section{DEVELOPMENT OF THE CLASSIFICATION APPROACHES}

In order to elucidate the relation of the proposed CUAL classification to the stratigraphic classification systems applied earlier, their backgrounds are briefly reviewed here.

\section{The Lithologic and Lithogenetic Approach}

The most widely applied systems for classifying the Quaternary overburden are based on varying combinations of lithological information (grain-size, mineralogy, color) and the genesis of the surficial $(<1 \mathrm{~m}$ or $>1 \mathrm{~m})$ deposits. The stratigraphic aspect is normally very limited (North American Geologic Map Data Model Science Language Technical Team, 2004; McMillan and Powell, 1999). These classifications give the necessary surficial base data for wide areas, but seldom meet any more demanding scientific or applied needs.

\section{The Morphogenetic and Morphostratigraphic Approach}

Morphostratigraphical schemes have been published by Willman and Frye (1970) and Nystuen (1986), and physical geographers have also traditionally favored this approach. This approach may apply in areas of sediment cover derived from one glacial cycle, but it cannot apply to terrains with deposits from multiple glacial events (cf. Möller, 2006).

\section{The Lithostratigraphic Approach (sensu lato)}

At the very beginning of systematic Quaternary research in Canada, Logan (1863) classified Quaternary units into lithostratigraphic formations in a similar manner to the strata from the older geological column. Later, in the late nineteenth and early twentieth centuries, when glacial geology was becoming increasingly segregated from Paleozoic and Precambrian geology (Willman and Frye, 1970), the lithologic and lithogenetic approach and the morphostratigraphic approach described above were developed.

In later years, however, a return to the application of lithostratigraphy occurred. Willman and Frye (1970) presented a systematic classification of the Pleistocene glacial deposits covering the Paleozoic bedrock of Illinois in terms of rock-stratigraphic units (= lithostratigraphic units) to be "defined and recognized on the basis of observable lithology without necessary regard to biological, time, or other types of criteria. They (rock-stratigraphic units) must be sufficiently distinctive to be recognizable by common field and subsurface methods" (p. 40). They added, however, "Once described, a rock-stratigraphic unit may be traced laterally, even though its lithologic character changes gradationally, so long as the integrity of the unit as a continuous body of rock can be recognized" (p. 40). They made this addition in order to amplify their lithostratigraphic classification criteria to meet the changing lithologies in their strata. The members in their scheme are lithologically distinctive, but most of them do not have the regional continuity to be mappable.

Lithostratigraphic units have been used in abundance to identify Quaternary deposits in the UK. In the 1970s, it was already common practice that lithologically varying units were accepted as formations, and members have come to be used for the lithologically more uniform parts of those formations (cf. Rose and Allen, 1977; Rose and Menzies, 1996). Earlier, Lüttig et al. (1969, p. 35) had proposed that a formation "is to be understood as a document of a genetically uniform sedimentation process, which may have led to the formation of a rock sequence more or less, in some cases even highly differing in single subunits, but of a uniform facies and genetic character." In this scheme, a member shows "a reasonable lithologic similarity ... so that the strata may belong to one cycle of sedimentation."

Although mixing genetic interpretation and descriptive criteria, the definitions of Rose and Allen (1977) and Lüttig et al. (1969) for a lithostratigraphic formation and member resemble the more descriptive criteria of Willman and Frye (1970). These definitions can be regarded as the basis for the BGS, Deltares, and MGS stratigraphical frameworks (cf. Rawson et al., 2002).

\section{Morpho(/Litho)-Stratigraphic Approach}

Recently in the UK, Hughes et al. (2005) presented a combined morpho(litho)stratigraphical approach in which the landform morphology was taken as an elemental part of the definition of the lithostratigraphic unit from which the landform was composed. This evidently works well with deposits derived from one glacial cycle but will meet problems when deposits of polygenetic landforms derived from multiple glacial cycles are classified (cf. Möller, 2006).

\section{The Depositional System Approach}

Some Quaternary researchers who have considered lithostratigraphy more strictly have tended to avoid its use, adopting instead the concept of depositional systems, for example, to classify their strata (Eyles et al., 1983). A depositional system was originally defined by Fisher and McGowen (1967) as an assemblage of genetically related facies.

\section{Allostratigraphic Approaches}

Geologists have always accepted unconformities as the limits between lithostratigraphic formations in pre-Quaternary stratigraphies, although it is the lithological change occurring at an unconformity that has been taken as the defining criterion for delimiting the units (Salvador, 1994).

One of the first researchers to define sedimentary packages that would today be called unconformity-bounded units/ allostratigraphic units/synthems (Salvador, 1994) was Caster (1934), who studied the Devonian coastal sequences of Pennsylvania and referred to sequences of differing age as parvafacies. Later, Forgotson (1957) spoke of the unconformity-bounded units as formats and other synonymous terms, such as the sequence offacies, facies tracts, facies families; the terms facies suites of Teichert, the bolosome of Wheeler, and the concept of genetic increment of strata of Bush have also been used (cf. NACSN, 2005, and ref. therein). Chang (1975) developed the 


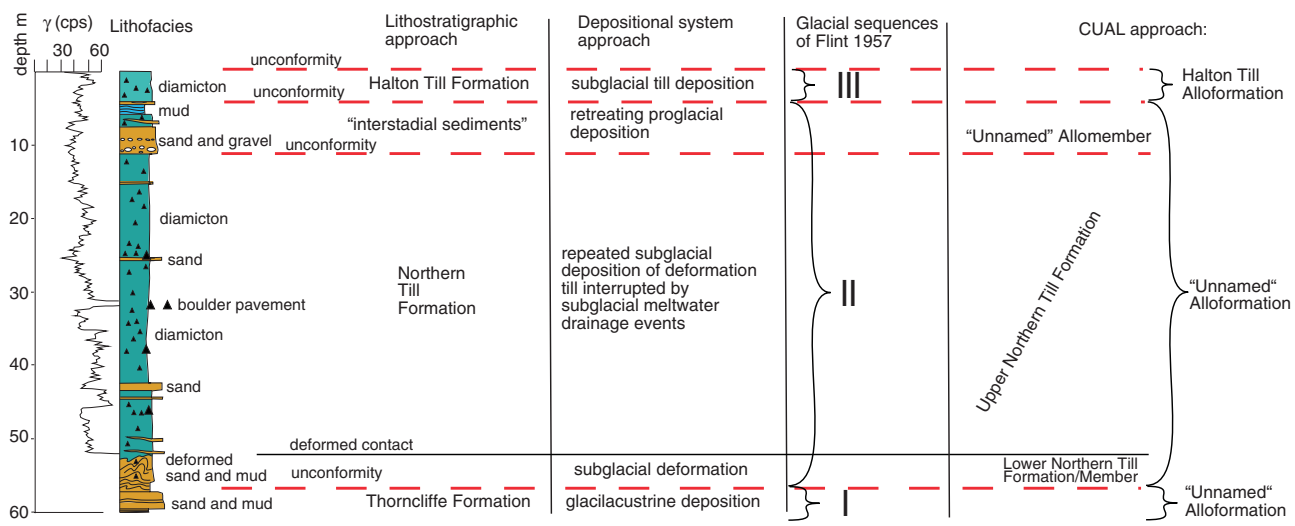

Figure 4. Application of the "combined use of allostratigraphy and lithostratigraphy" (CUAL) approach to a Quaternary glacial sequence in the Toronto area, Canada. The figure demonstrates the basic principles of CUAL classification in relation to the lithostratigraphic, depositional system, and glacial sequence approaches. The figure shows the natural gamma-ray emissions (cps-counts per second) and a simplified lithofacies column together with the positions of the major unconformities and deformed contacts within the section (modified from Boyce and Eyles, 2000), providing a basis for the CUAL classification. This tentative CUAL classification shows only the categories of the units (lithostratigraphic/allostratigraphic) and their hierarchy, with the most obvious possible names, deliberately leaving most of the units unnamed. The allounits are bounded by unconformities, while the lithostratigraphic units are separated by gradational or deformed contacts.

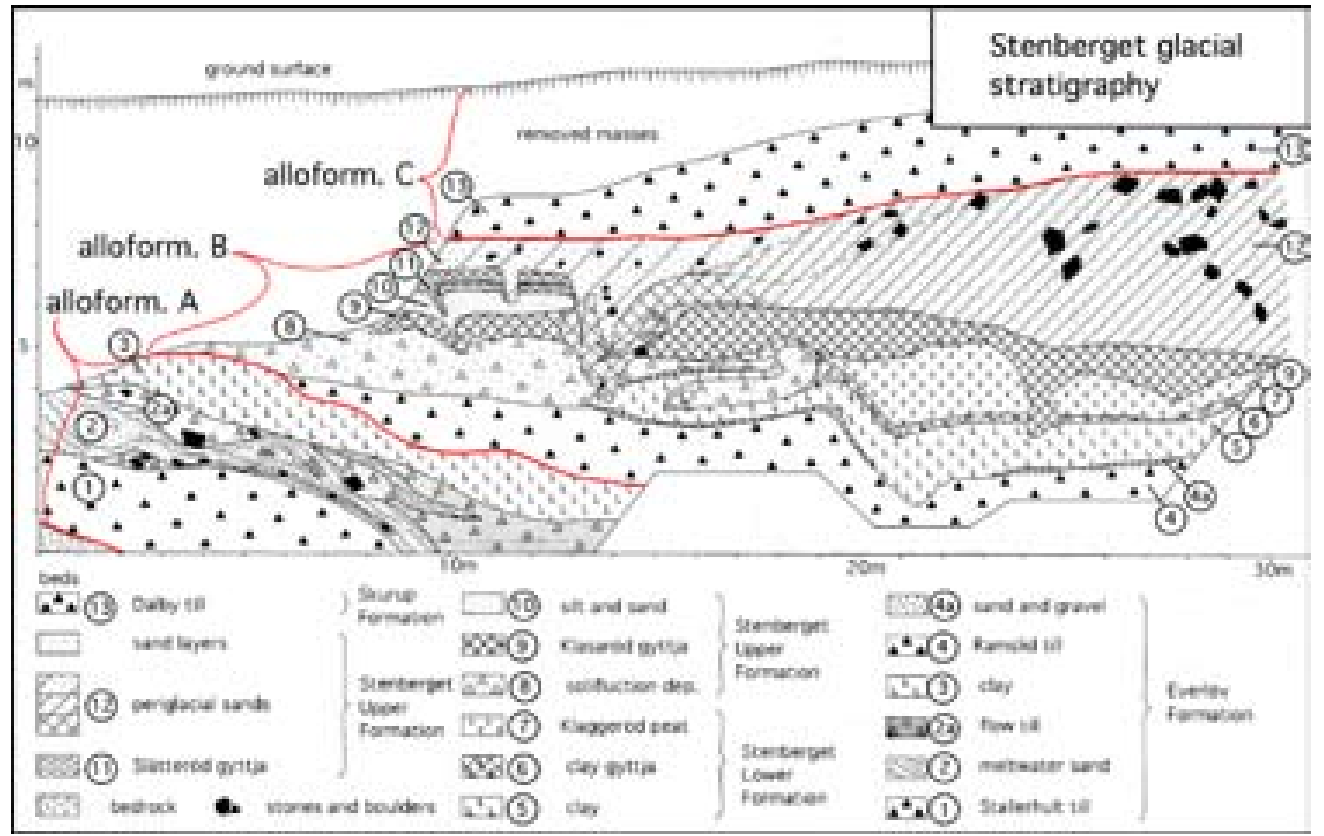

Figure 5. A glacial section located in a Precambrian gneiss-granite bedrock area at Stenberget, southern Sweden, divided into three alloformations (A-C) according to the erosive unconformities at the bases of the three till layers (red lines). Each of these alloformations shows a succession from till to sorted sediments. The tills of the alloformations and the alloformations as such have a better mappability than the sorted units. Modified from Lagerlund (1980), who applied detailed formal and informal lithostratigraphic nomenclature for the units in the section.

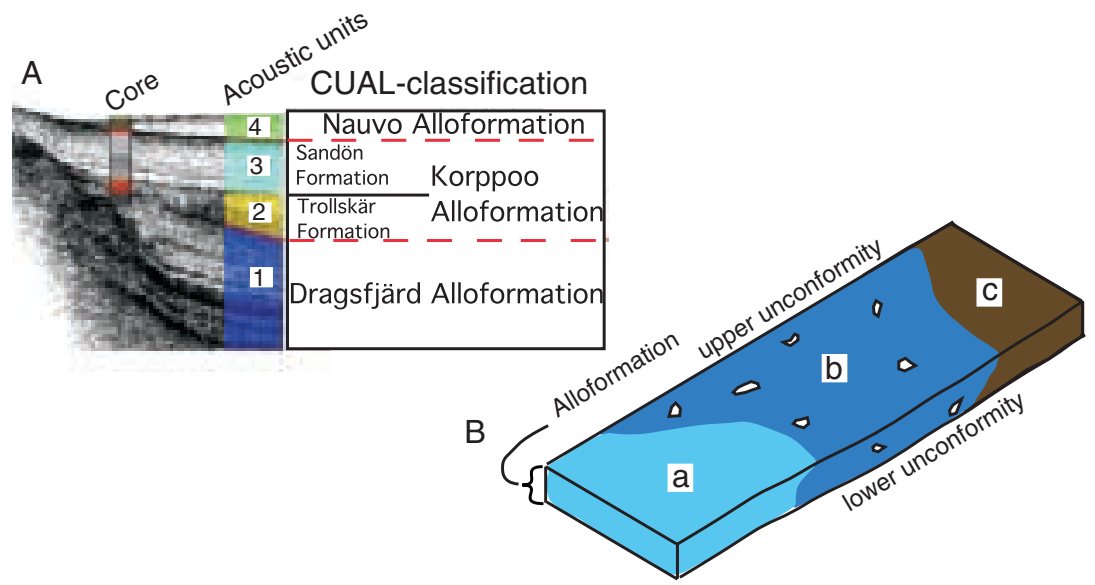

Figure 6. Application of the "combined use of allostratigraphy and lithostratigraphy" (CUAL) approach. (A) Classification of offshore Baltic Sea sediments based on acoustic soundings and core data, modified from Virtasalo et al. (2005). Dashed line-unconformity; continuous line-gradual contact. The Korppoo Alloformation is divided into two lithostratigraphic formations according to the gradual lithological change at their boundary. (B) Hypothetical example of an unconformity-bounded till bed defined as an allostratigraphic formation. The lateral variation in the lithology within the till bed is used to define lithostratigraphic units $(\mathrm{a}-\mathrm{c})$ where appropriate. 
term synthem for the unconformity-bounded units in South Korean Paleozoic-Mesozoic sequences.

Walker and James (1992) stressed the advantages of the allostratigraphic approach in their textbook and presented a number of good case studies of its application. The NACSN (2005) also proposed that allostratigraphic units should be used as formal units, especially in Neogene and Quaternary strata.

Allostratigraphy and lithostratigraphy have in some cases been used together, and Chang (1975) showed how lithostratigraphic formations form elemental parts of his synthems. The term folgen has been used recently for unconformity-bounded units in the Triassic sequences of Germany (Lutz et al., 2005), with lithostratigraphic formations constituting parts of these (Nitsch, 2005).

\section{Allostratigraphy in Quaternary Deposits}

The allostratigraphic approach has proved easy to apply in the case of fluvial Quaternary deposits, where the unconformities are well developed (Zuchiewicz, 1988; Autin, 1992; Benvenuti, 1997; Straffin et al., 1999; Sinha et al., 2005). Similarly, in offshore studies, the seismic and acoustic profiles reveal the unconformities quite clearly (Hiscott, 2001; Virtasalo et al., 2005). In mountainous regions, the differences in elevation of the glacial deposits have facilitated delimitation of the allostratigraphic units in the field (cf. Hughes et al., 2005, and references therein; Hughes, 2006).

The only work with which we are familiar that combines lithostratigraphic and allostratigraphic approaches is that of Rijsdijk et al. (2005), who covers the Neogene and Quaternary deposits of the Netherlands. Here the broadly defined lithostratigraphic formations of Weerts and Westerhoff (2007) are included within allostratigraphic formations. This work deals with deposits on the same scale as in sequence stratigraphy. When allostratigraphy has been applied to Quaternary glaciated terrain deposits other than in mountainous regions, it has been used in an interpretative manner (Little, 2005) and not descriptively.

\section{The Glacial Sequence Stratigraphic Approach}

It is notable that Flint (1957) already used the term glacial sequence to refer to a basic depositional element composed of a till bed and overlying sorted sediments in a Quaternary glaciated terrain, but its use has never been firmly established in the same manner as sequence in the sequence stratigraphy context of Vail et al. (1977). However, Powell and Cooper (2002) have recently applied a glacial sequence stratigraphic nomenclature to seismically well-studied deposits in temperate continental shelves.

In summary, it can be concluded that all the approaches described-lithostratigraphic classification (sensu lato), the morpho(litho)stratigraphic, the depositional system, and the allostratigraphic and glacial sequence stratigraphic approaches-are in practice quite identical in the way in which they have been applied to Quaternary deposits, as they mostly define unconformity-bounded genetic units (Fig. 4). Although exceptions always exist, many of the groups and formations defined in the Deltares, BGS, and MGS lithostratigraphic frameworks could often be alternatively, or even more likely, regarded as unconformity-bounded allostratigraphic units (cf. Chang, 1975; McMillan, 2005) or glacial sequences. They are often delimited by major transgressive and regressive regional unconformities or by unconformities and diastems caused by glacial erosion or shifts in the focus of glaciofluvial deposition. It is simply that the segregation of the research community into different geology/geography schools and traditions with different paradigmal backgrounds has caused multiple terminologies to develop.

\section{The CUAL Approach}

The true nature of the Quaternary depositional units in glaciated shield areas is that they are arranged in unconformitybounded, lithologically varying packages, so allostratigraphy may be regarded as the most promising descriptive approach for stratigraphic classification (cf. NACSN, 2005). Lithostratigraphy is undoubtedly applicable as well, but it should be used in a stricter manner than in the examples herein.

In the CUAL approach, the allounits are given preference, and the lithostratigraphic units are subordinate to the allostratigraphy. It is in this aspect that the scheme differs from the proposals of the NACSN (2005). This modification in relation to the previous Quaternary classifications may sound purely semantic, but it is important in that lithostratigraphy can now be applied more strictly (Shultz, 1982) to fill in the lithostratigraphically mappable "details" in the allostratigraphic framework. When the present land surface forms the upper bounding surface of a superficial allounit, then the spatial morpho(litho)stratigraphical information can be applied to the delimitation of the unit.

The main principles and characteristics of the CUAL stratigraphic classification are as follows:

1. A preference for defining mappable allostratigraphic formations. These are normally larger than the lithostratigraphic units in glaciated terrains (Figs. 1 and 4-6).

2. When lithologically identifiable, reasonably homogeneous, and mappable lithostratigraphic formations (sensu stricto) can be defined within an alloformation, this should be done (Figs. 1, 4, 6A, and 6B).

3. Where appropriate, an entire alloformation can be subdivided into either lithostratigraphic units (formations, members; Figs. 1, 6A, and 6B), lower-rank allostratigraphic units (allomembers), or a combination of these (Figs. 1 and 4).

4. Allomembers or members need not be mappable, but can be. It is accepted that a lithostratigraphic member does not need to be part of a lithostratigraphic formation but can be a part of an alloformation.

5. If an alloformation has such a diverse or chaotic lithology that its subdivision is not reasonable, its internal lithological variation should be broadly described when it is defined.

6. The preference for defining allostratigraphic units means that in cases where a lithologically uniform unit is cut by unconformities, which is less common in glaciogenic terrains, the unit should be named in accordance with the allostratigraphy.

7. The single definition criterion for an allounit should always be its bounding unconformities, the nature of which need to be properly described. The nature of a boundary between allounits may change from that of a clear unconformity to a deformed bed or even a conformable 
bed in the same way as a correlative conformity surface in sequence stratigraphy.

\section{DISCUSSION}

Formal stratigraphic classification is a fundamental scientific tool for developing a regional knowledge of any period in Earth's history. For the subfield of Quaternary geology, the selection of stratigraphic classification criteria is as important a paradigmal decision as was the adoption of sequence stratigraphy for petroleum geology in the 1980s. The CUAL approach proposed here provides a hierarchical classification system for glaciogenic deposits and creates a sound basis for detailed chronostratigraphic and diachronic work (Johnson et al., 1997) in order to improve our understanding of the complicated Quaternary couplings of astronomic forcing, climatic change, and continental glacial dynamics that have determined the distribution and nature of glacial depositional and erosional products.

Although Quaternary glaciated terrain deposits have geologically unique properties, they should be studied using the same type of stratigraphic toolbox as pre-Quaternary strata. The establishment of a stratigraphic framework system using a CUAL approach would require more excavations and surficial drilling as well as wireline geophysics, ground-penetrating radar, shallow seismics, acoustic soundings, and other geophysical methods that are still under development.

Major unconformities may sometimes be difficult to define in unconsolidated glacial-terrain deposits. This may be caused by, for example, multiple glacial scouring, which has created repeated unconformities. Although allostratigraphy and the CUAL approach are intended to be objective and descriptive methods, we have to accept that the definition and hierarchical ranking of unconformities will sometimes include more or less interpretation. In order to place our major regional unconformities, we have to evaluate the importance of (a) the possible changes in lithology, (b) the adjacent lithofacies successions/ associations within the section, and (c) the physical expression of an unconformity or its reflection in the geophysical data. Therefore, we cannot completely avoid interpretation if we aim to construct a stratigraphical framework for an area. Ultimately, it may be of less importance what kind of data are used for identifying the presence of an unconformity than what kinds of stratigraphic units one defines and uses as basic units in a formal stratigraphic framework. As sequence stratigraphy has shown, unconformity-bounded units explain geologic history in a better way than lithostratigraphy (e.g., Gutteridge, 2008).

\section{ACKNOWLEDGMENTS}

We wish to express our sincere thanks to W.E. Westerhoff, H.J.T. Weerts, and A.A. McMillan for discussions and comments on this theme, as well as to the three anonymous reviewers for their constructive comments.

\section{REFERENCES CITED}

Auri, J., 2006, Varhais-Veikselin Herning-, Brörup-, Rederstall- ja Odderade-kroonien kasvillisuuskehitys Björkössä, Merenkurkussa [M.Sc. thesis]: University of Turku, 62 p.

Autin, W.J., 1992, Use of alloformations for definition of Holocene meander belts in the middle Amite river, southeastern Lousiana: Geological Society of America Bulletin, v. 104, p. 233-241, doi: 10.1130/ 0016-7606(1992)104<0233:UOAFDO>2.3.CO;2.
Benvenuti, M., 1997, Physical stratigraphy of the fluvio-lacustrine Mugello basin (Plio-Pleistocene, northern Apennines, Italy): Giornale di Geologia, v. 59, p. 91-111.

Boyce, I.J., and Eyles, N., 2000, Architectural element analysis applied to glacial deposits: Internal geometry of a late Pleistocene till sheet, Ontario, Canada: Geological Society of America Bulletin, v. 112, p. 98-118, doi: 10.1130/0016-7606(2000)112<0098:AEAATG>2.3.CO;2.

Brauer, A., and Negendank, J.F.W., 2004, The European Lake Drilling Programme (ELDP) from 1996-2001: High-resolution lake sediment records in climate and environmental variability studies: Quaternary International, v. 122, p. 1-5, doi: 10.1016/j.quaint.2004.01.034.

Brookfield, M.E., and Martini, I.P., 1999, Facies architecture and sequence stratigraphy in glacially influenced basins: Basic problems and water level/glacial input controls (with an example from the Quaternary of Ontario, Canada): Sedimentary Geology, v. 123, p. 183-197, doi: 10.1016/S0037-0738(98)00088-8.

Caster, K.E., 1934, The stratigraphy and paleontology of northwestern Pennsylvania, Part 1, Stratigraphy: Bulletins of American Paleontology, v. $21,185 \mathrm{p}$.

Chang, K.H., 1975, Unconformity bounded stratigraphical units: Geological Society of America Bulletin, v. 86, p. 1544-1552, doi: 10.1130/ 0016-7606(1975)86<1544:USU>2.0.CO;2.

EPICA (European Project for Ice Coring in Antarctica) community members, 2004, Eight glacial cycles from an Antarctic ice core: Nature, v. 429, p. $623-628$.

European Union, 2007, Directive 2007/2/EC of the European Parliament and of the Council of 14 March 2007 establishing an Infrastructure for Spatial Information in the European Community (INSPIRE), Official Journal of the European Union L108, v. 50, 25 April 2007, p. 1-14.

Eyles, N., Eyles, C.H., and Miall, A.D., 1983, Lithofacies types and vertical profile models; an alternative approach to the description and environmental interpretation of glacial diamict and diamictite sequences: Sedimentology, v. 30, p. 393-410, doi: 10.1111/j.1365-3091.1983. tb00679.x.

Eyles, N., Miall, A.D., and Eyles, C.H., 1984, Lithofacies types and vertical profile models; an alternative approach to the description and environmental interpretation of glacial diamict and diamictite sequences: Reply: Sedimentology, v. 31, p. 883-898, doi: 10.1111/j.13653091.1984.tb00894.x.

Fisher, W.L., and McGowen, J.H., 1967, Depositional systems in the Wilcox Group at Texas and their relationship to occurrence of oil and gas: Transactions of the Gulf Coast Association Geological Societies, v. 17 , p. $105-125$.

Flint, R.F., 1957, Glacial and Pleistocene Geology: Wiley, New York, 553 p.

Forgotson, J.M., Jr., 1957, Nature, usage and definition of marker-defined vertically segregated rock units: AAPG Bulletin, v. 41, no. 9, p. 21082113.

Gibbard, P.L., Boreham, S., Cohen, K.M., and Moscariello, A., 2007, Global chronostratigraphical correlation table for the last 2.7 million years: Boreas v. 34, no. 1, unpaginated (modified/updated 2007).

Gutteridge, P., 2008, Who needs lithostratigraphy?: Geoscientist, v. 18, no. 3, http://geolsoc.org.uk/page3249_en.html (last accessed 4 Oct. 2008).

Heathcote, J.A., and Michie, U.McL., 2004, Estimating hydrogeological conditions over the last $120 \mathrm{ka}$ : An example from the Sellafield area, UK: Journal of the Geological Society, v. 161, no. 11, p. 1-17.

Hiscott, R.N., 2001, Depositional sequences controlled by high rates of sediment supply, sea-level variations, and growth faulting: The Quaternary Baram Delta of northwestern Borneo: Marine Geology, v. 175, p. 67-102, doi: 10.1016/S0025-3227(01)00118-9.

Hughes, P.D., 2006, Morphostratigraphy/Allostratigraphy, in Elias, S.A., ed., Encyclopedia of Quaternary Science: London, Elsevier, p. 28412847.

Hughes, P.D., Gibbard, P.L., and Woodward, J.C., 2005, Quaternary glacial records in mountain regions: A formal stratigraphical approach: Episodes, v. 28, p. 85-92. 
Intergovernmental Panel on Climate Change (IPCC), 2007, Climate Change 2007: The physical science basis. Contribution of Working Group I to the Fourth Assessment Report of the Intergovernmental Panel on Climate Change, Solomon, S., Qin, D., Manning, M., Chen, Z., Marquis, M., Avery, K.B., Tignor, M., and Miller, H.L., eds.: Cambridge, UK, Cambridge University Press, 996 p.

Johnson, M.D., Harris, K.L., Hobbs, H.C., Jennings, C.E., Knaeble, A.R., Lusardi, B.A., and Meyer, G.N., 2005, Formal Quaternary lithostratigraphy of Minnesota; a progress report: Geological Society of America Abstracts with Programs, v. 37, no. 5, p. 91.

Johnson, W.H., Hansel, A.K., Bettis, E.A., III, Karrow, P.F., Larson, G.J., Lowell, T.V., and Schneider, A.F., 1997, Late Quaternary temporal and event classifications Great Lakes region: North America: Quaternary Research, v. 47, p. 1-12.

Karrow, P.F., Dreimanis, A., and Barnett, P.J., 2000, A proposed diachronic revision of late Quaternary time-stratigraphic classification in the eastern and northern Great Lakes Area: Quaternary Research, v. 54, p. 1-12, doi: 10.1006/qres.2000.2144.

Lagerlund, E., 1980, Litostratigrafisk indelning av Västskånes Pleistocen och en ny glaciations-modell för Weichsel: University of Lund, Department of Quaternary Geology, Report 21, 120 p.

Linden, A., 1975, Till Petrographical Studies in an Archaean Bedrock Area in Southern Central Sweden: Striae, v. 1, 57 p.

Little, E.C., 2005, Sedimentology and stratigraphy for Quaternary deposits of the Russian plain [Ph.D. thesis]: Edmonton, University of Alberta, $271 \mathrm{p}$.

Logan, W.E., 1863, Geology of Canada: Montreal, Dawson Brothers, 983 p.

Lutz, M., Etzold, A., Kading, K.C., Lepper, J., Hagdorn, H., Nitsch, E., and Menning, M., 2005, Lithofacies and control surfaces: Fundamentals of a dual lithostratigraphic classification: Newsletters on Stratigraphy, v. 41, p. 211-223, doi: 10.1127/0078-0421/2005/0041-0211.

Lüttig, G.W., Paepe, R., West, R.G., and Zagwijn, W.H., 1969, Key to the interpretation and nomenclature of Quaternary stratigraphy (first and provisional edition): Hannover, International Union for Quaternary Research (INQUA), Commission of Stratigraphy, $46 \mathrm{p}$.

McMillan, A.A., 2005, A provisional Quaternary and Neogene lithostratigraphical framework for Great Britain: Geologie en Mijnbouw, v. 84, p. 87-107.

McMillan, A.A., and Powell, J.H., 1999, BGS rock classification scheme: The classification of artificial (man-made) ground and natural superficial deposits: Applications for geological maps and datasets in the UK: British Geological Survey Research Report RR/99/4, 65 p.

Miall, A.D., 1997, The Geology of Stratigraphic Sequences: Berlin, Springer Verlag, $433 \mathrm{p}$.

Möller, P., 2006, Rogen moraine: An example of glacial reshaping of preexisting landforms: Quaternary Science Reviews, v. 25, p. 362-389, doi: 10.1016/j.quascirev.2005.01.011.

Nitsch, E., 2005, Der Keuper in der Stratigraphichen Tabelle von Deutschland 2002: Formationen und Folgen: Newsletters on Stratigraphy, v. 41, p. 159-171, doi: 10.1127/0078-0421/2005/0041-0159.

North American Commission for Stratigraphic Nomenclature, 2005, North American Stratigraphic Code: The American Association of Petroleum Geologists Bulletin, v. 89, p. 1547-1591.

North American Geologic Map Data Model Science Language Technical Team, 2004, Sedimentary materials: Science language for their classification, description, and interpretation in digital geologic-map databases, version $1.0(12 / 18 / 2004)$.

Nystuen, J.P., 1986, Regler och råd for navnsetting av geologiske enheter i Norge. Av Norsk Stratigrafisk Komite: Norsk Geologisk Tidsskrift, v. 66, Suppl. 1, p. 1-96.

Powell, R.D., and Cooper, J.M., 2002, A glacial sequence stratigraphical model for temperate, glaciated continental shelves, in Dowdeswell, J.A., and Ó Cofaigh, C., eds., Glacier-Influenced Sedimentation on High-Latitude Continental Margins: London, Geological Society Special Publication 203, p. 215-244.

Rawson, P.F., Allen, P.M., Brenchley, P.J., Cope, J.C.W., Gale, A.S., Evans, J.A., Gibbard, P.L., Gregory, F.J., Hailwood, E.A., Hesselbo, S.P.,
Knox, R.W.O’B., Marshall, J.E.A., Oates, M., Riley, N.J., Smith, A.G., Trevin, N., and Zalasiewicz, J.A., 2002, Stratigraphic Procedure: London, Geological Society Professional Handbook, 57 p.

Rijsdijk, K.F., Passhier, S., Weerts, H.J.T., Laban, C., wan Leeuwen, R.J.W., and Ebbing, J.H.J., 2005, Revised Upper Cenozoic stratigraphy of the Dutch sector of the North Sea Basin: Towards an integrated lithostratigraphic, seismostratigraphic and allostratigraphic approach: Geologie en Mijnbouw, v. 84, p. 129-146.

Rose, J., and Allen, P., 1977, Middle Pleistocene stratigraphy in South-East Suffolk: Journal of the Geological Society, v. 133, p. 83-102, doi: 10.1144/gsjgs.133.1.0083.

Rose, J., and Menzies, J., 1996, Glacial stratigraphy, in Menzies, J., ed., Past glacial environments: Sediments, forms, techniques: Oxford, Butterworth Heinemann, p. 253-284.

Saarnisto, M., and Peltoniemi, H., 1984, Glacial stratigraphy and compositional properties of till in Kainuu, eastern Finland: Fennia, v. 162, p. 163-199.

Salvador, A., editor, 1994, International Stratigraphic Guide: The International Union of Geological Sciences and The Geological Society of America, $214 \mathrm{p}$.

Shultz, E.H., 1982, The Chronosome and supersome: Terms proposed for low-rank chronostratigraphic units: Canadian Petroleum Geology, v. 30, p. 29-33.

Sinha, R., Gibling, M.R., Tandon, S.K., Jain, V., and Dasgupta, A.S., 2005, Quaternary stratigraphy and sedimentology of the Korea section on the Betwa River, southern Gangetic Plains, Uttar Pradesh: Journal of the Geological Society of India, v. 65, p. 441-450.

Straffin, E.C., Blum, M.D., Colls, A., and Stokes, S., 1999, Alluvial stratigraphy of the Loire and Arroux Rivers (Burgundy, France): Quaternaire, v. 10 , p. $271-282$.

Vail, P.R., Mitchum, R.M., and Thompson, S., III, 1977, Seismic stratigraphy and global changes of sea level, part 3: Relative changes of sea level from coastal onlap, in Patyon, C.E., ed., Seismic StratigraphyApplications to Hydrocarbon Exploration: American Association of Petroleum Geologists Memoir 26, p. 63-81.

Virtasalo, J.J., Kotilainen, A.T., and Räsänen, M.E., 2005, Holocene stratigraphy of the Archipelago Sea, northern Baltic Sea: The definitions and descriptions of the Dragsfjärd: Korppoo and Nauvo Alloformations: Baltica, v. 18, p. 83-97.

Walker, R., and James, N.P., 1992, Facies models: St. Johns, Newfoundland, Geological Association of Canada, $454 \mathrm{p}$.

Weerts, H.J.T., and Westerhoff, W.E., 2007, Lithostratigraphy, in Elias, S.A., ed., Encyclopedia of Quaternary Science: London, Elsevier, p. 28262840.

Weerts, H.J.T., Westerhoff, W.E., Cleveringa, P., Bierkens, M.F.P., Veldkamp, J.G., and Rijsdijk, K.F., 2005, Quaternary geological mapping of the lowlands of The Netherlands: Quaternary International, v. 133-134, May 2005, p. 159-178.

Willman, H.B., and Frye, J.C., 1970, Pleistocene stratigraphy of Illinois: Illinois State Geological Survey Bulletin, v. 94, 204 p.

Zuchiewicz, W., 1988, Allostratigraphy of Quaternary deposits in Central Carpathian valleys: A new proposal: Quaternary Studies in Poland, v. 8, p. 61-65.

Manuscript received 23 June 2008; accepted 20 November 2008. 